\title{
AN OVERVIEW OF URBAN CHANGE PROCESS IN ISTANBUL METROPOLIS
}

\author{
Nilüfer Kart Aktaş, Istanbul University, \\ Hande Sanem Çınar, Istanbul University
}

\begin{abstract}
At every stage of human history, people migrate by force or by their own will. Both forced and willing migrations are caused by wars, poverty and a higher expectation for better living standards, employment, residence, social status, quality life, education, and others. In Turkey, migration from rural to urban areas that took place between the 1950s and 1980s has caused millions of people to migrate to cosmopolitan cities, like Istanbul. One of the main reasons for immigration to the city was due to the quality of life in the city and rural areas. This geographically displaced process of millions of people has influenced economic, social and cultural change and transformation in both the city and the village. Migrants often migrate to cities without proper knowledge, skills, and expertise, which significantly affect their economic, social and cultural status in the city where they have moved. For this reason, immigrants usually use their own "integration strategies". Most of the migrants could not adapt to the rapid life of the metropolis, so they preferred to live in shanties by isolating themselves from metropolitan life, which became one of the major urban problems. The Urban regeneration process, which entered our life rapidly as a result of the great earthquake that occurred in 1999, led to rapid changes in both the social and physical space and even the transformation in Istanbul. Thus, this study aims to analyze the physical, spatial and social changes in the urban regeneration process of the regions where the first shanty was established in Istanbul. An assessment of this shanty in Istanbul is significant because it received the biggest number of migrants between the 1950s and 1980s. Consequently, urban, economic, social and cultural effects of these changes continue to shape present-day Istanbul's urban system and urban identity.
\end{abstract}

Keywords: urban change, urban transformation, urbanization, Istanbul, Turkey. 


\section{Introduction}

Cosmopolitan and well-managed cities offer important civic and cultural opportunities for citizens. Cities have always been focal points for economic growth, innovation, and employment. Indeed, many cities grew historically out of some natural advantage in transport or raw material supply. Cities are also centers of modern living, where indicators of general health and wellbeing, literacy, women's status, and social mobility are typically highest. Finally, cities are also important social and cultural centers that house museums, art galleries, film industries, theaters, fashion houses, and other important cultural centers (Cohen, 2006).

Besides all these advantages of cities, many urban areas have experienced dramatic growth, as a result of rapid population growth, called urbanization. Urbanization is one of the significant phenomena of the modern world. Rapid urbanization, over urbanization, shanty houses, slums, crime rates, degradation of the environment, even the ozone layer are among the issues discussed within this context (Mbanaso and Ozden, 2017).

Urbanization and city growth are often shaped by several different factors including rural-urban migration, natural population increase, and annexation. Because rates of natural population increase are generally slightly lower in urban than in rural areas, the principal reasons for rising levels of urbanization are rural-urban migration. Then, migrations are determined by the geographic expansion of urban areas through annexations and the transformation and reclassification of rural villages into small urban settlements. The expansion of the metropolitan periphery can be caused both by the arrival of new migrants and by the suburbanization of the middle class out of the central city. The relative importance of each of these various causes of urbanization and suburbanization varies both within and between regions and countries (Cohen, 2006).

Migration is not just a social phenomenon but a process (Ulu and Karakoç, 2004). In this process, the migrant population met their own housing need by constructing shanties on the treasury or private land in the city center (Ataöv and Osmay, 2007). It has been observed that together with the shanties, infrastructural deficiencies, crime and misery places, different social stratum, and urban spatial structures have changed. While the social groups in the uppermost levels had to be located outward from the center, with the change in the social structure existing in the cities, every social group in the city became intertwined after the differentiation in economic activities (Ulu and Karakoç, 2004). This situation has caused the change in urban culture and identity.

\section{The Process of Migration and Urban Change}

Roberts, 2000, commenting on the urban change process in the years following:

1950 Reconstruction: areas close to the urban center and nearby neighborhood units, 1960 Revitalization: the development of social facilities and the formation of spacious and livable areas,

1970 Renewal: the development of public and private sector resources, renewed urban infrastructure, and the increase in environmental concerns.

1980 Redevelopment: projects, farther city projects, special sector focus, partnership development, environmental approaches,

1990 Regeneration: the tendency of a detailed approach to implementation and policy, the adoption of a strategic perspective, the development of regional actions, the sustainable environment.

To understand the phenomenon of migration in Turkey, it is necessary to look at the dynamic changes. The first radical change experienced by the country since the founding of the Republic took place during the 1950s (Çağlayan, 2013). In Turkey the establishment of early squatters resulted in early unplanned, dysfunctional and environmentally hazard settlements. These squatters, far from large urban centers, 
caused different urban, economic, social and cultural changes and transformations. This phenomenon has also manifested itself in various parts of the world (Es, 2012).

In the 1980s, squatter housing areas have again been considered as problem areas, which have to be transformed for the capitalization of global interests, in the name of urban rent. These areas could have been transformed into prestige areas to increase the physical and visual wealth of the city. Thus, first with the improvement plans and later with the urban transformation projects, squatter housing areas have been subject to urban renewal for the betterment of urban space (Dündar,2001). In Turkey, the first thing that comes to mind is the transformation of shanties as the environmentally sustainable transformation of the urban areas. Urban regeneration is first life safety and being prepared for earthquakes within today's conditions. In 2000, new legislation on urban regeneration was introduced. "Urban rents" were taken as a source of transformation in legal regulation, and the municipality has been able to obtain "forced" and "urban rent" inflows to the municipalities, which have remained in areas closer to the city center (Koçak and Tolanlar, 2008).

Urban regeneration is primarily concerned with the dearth of civic criteria and factors that influence and shape society as a whole, on the basis of "quality of urban life" or "urban livability". It is gratifying to hear some issues, which directly affect all of us and future generations, such as urban development, urbanization, urbanism, livable cities, urban security, urban disaster management, urban renewal. Urban regeneration law and process provide a good opportunity to achieve a total "urban renaissance" (Es, 2012).

\section{Urban Change Dynamics in European Istanbul}

Istanbul is Turkey's social, cultural, economic, and one of the most dynamic cities. Istanbul has become the focus of attention as a result of increased urbanization and migrations. According to TSI data, Istanbul, which has a population of 3 million in 1970, has reached 14 million by 2014 (Belge and Çeker, 2015). As of 2018, Istanbul is the most populated city in Turkey with 15 million 29,231 people (URL 1, 2018).

While every urban intervention in Istanbul is handled under the heading of urban regeneration, the meaning of this concept is also dispersed. The concept takes the form of a prestige project on one side of the city and a new residential area on the other side (Kahraman. 2006). In particular, the first of these dilemmas took place in the Beyoğlu, Fatih, Zeytinburnu and Kagithane regions, which are among the most important districts of Istanbul on the European side (Figure 1).

Because the migrating population to Istanbul is close to the central business areas (CBD) first and the residential prices are attractive, migrants have settled in the historical districts like Beyoğlu (Galata, Cihangir, Tarlabaşı) which is the most important part of Istanbul. In addition, a large part of these neighborhoods has a heterogeneous structure with minorities and foreigners since the Ottoman Empire period. This is another reason why migrants settle in this part of Istanbul. Being migrant settlements, many old dwellings in these areas are in ruins and have been neglected (Uysal, 2006). Actually, a total of 237 risky buildings were identified within the scope of the transformation, of which 202 were demolished and reconstructed. The remaining 35 are waiting to be demolished. There is a collective transformation project in Tarlabaşı (URL 3, 2018). 


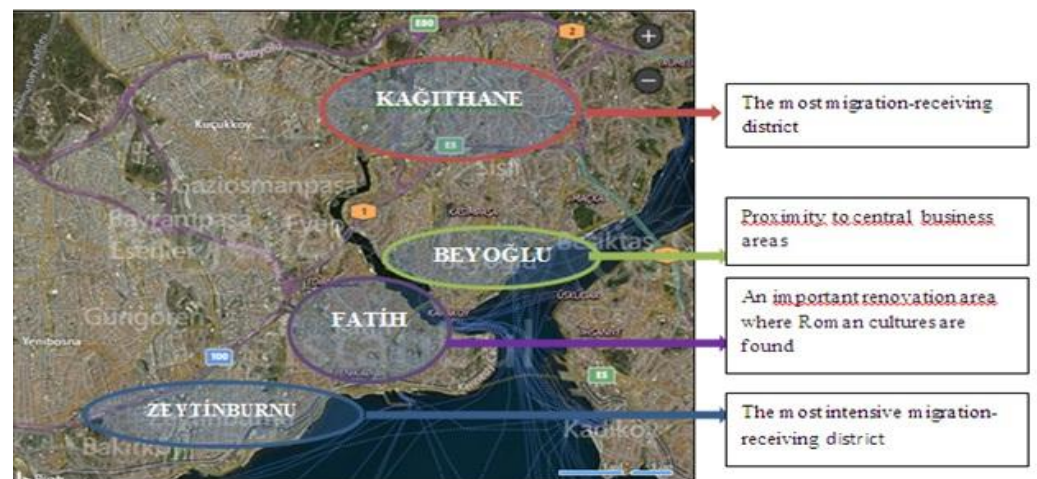

Figure 1. Location map of Zeytinburnu, Fatih, Beyoğlu and Kağıthane (URL 2, 2018)

The processes of gentrification in Galata and Cihangir began with the settlement of a number of contemporary art galleries. Today, these regions have become the focus of large institutions (Figure 2, Figure 3).

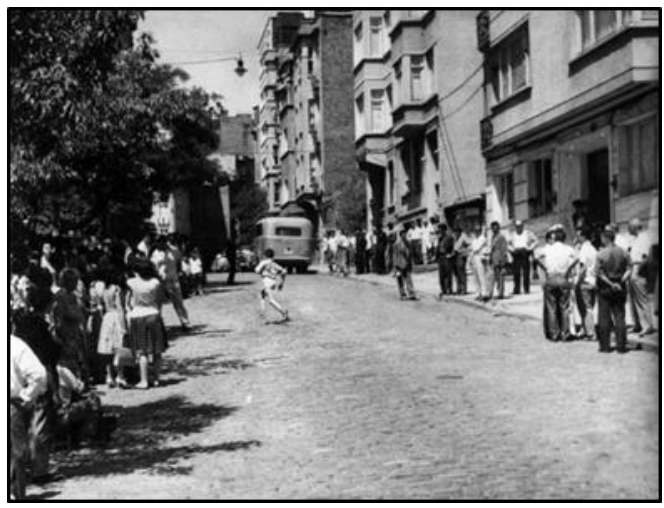

Figure 2. Cihangir- before (URL 4, 2018)

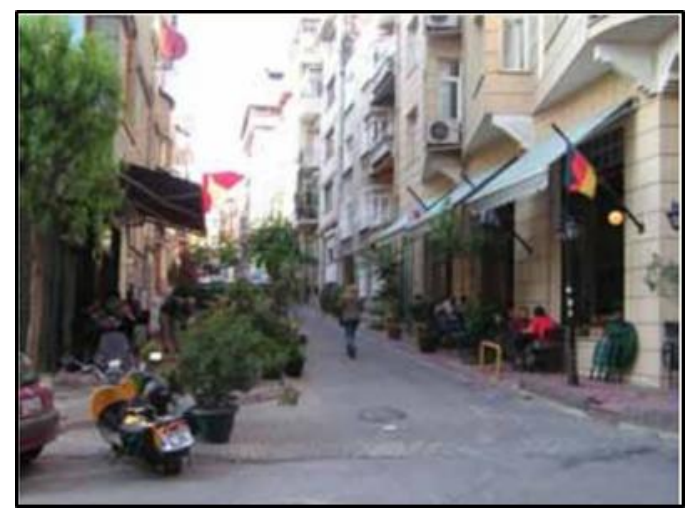

Figure 3. Cihangir-after (URL 5, 2018)

The municipality also promotes renovation projects in these regions. The transformation project of the Tarlabaşı region is the result of such a tendency (Özkan, 2011). Tarlabaşı is aimed at transforming the 
region from an area where people can easily move around, whereby safety and security are ensured (Figure 4).
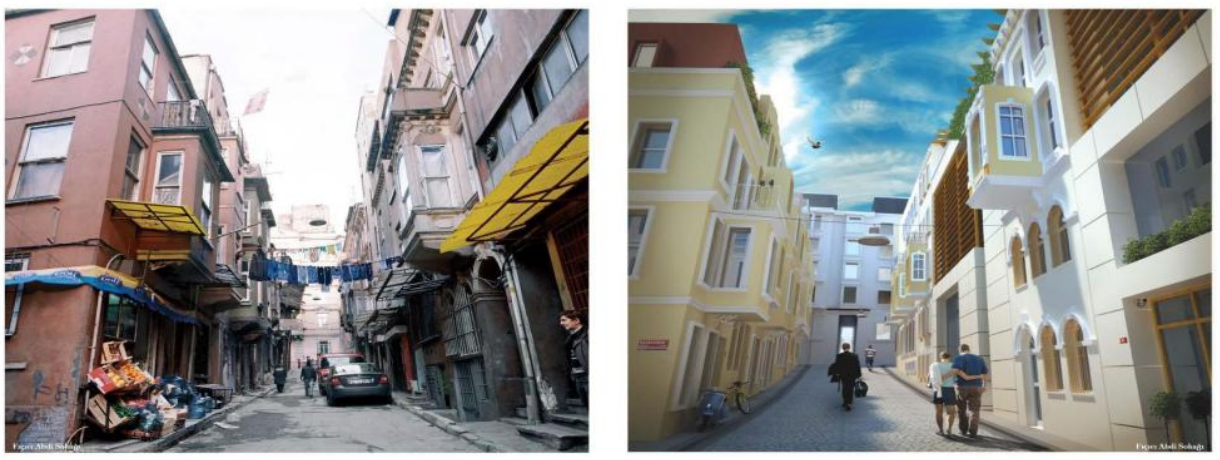

Figure 4. The view from Tarlabaşı Urban Renewal Area, Before-After (URL 6, 2018).

Sulukule, located in Fatih, the important part of Istanbul, has been one of the entertainment centers of Istanbul since the Ottoman period. In some sources, Sulukule is shown as the only Roman settlement on Earth after India (Altınöz, 2007). The culture of life in Sulukule, which continues in the Ottoman and Republican periods, has been inundated by the policies that the state has implemented, especially since the 1990s. With the rapid increase in poverty that exists in the area, the region has entered a collapse process. With the Sulukule Renewal Project, the population structure of the existing urban fabric and Sulukule has been ignored and the area has been redesigned as empty land.

Due to the urban regeneration project, the destruction of the area began in 2006 when the Roma were removed from their homes to a residential area built outside the city (URL 7, 2018). In this way, traditional street textures and structures were removed from the history, and the region was changed in its characteristic usage pattern (Figure 5, Figure 6) (Kıyak Ingin and Islam, 2011). Even if the ethnic identity is emphasized, wealthy families from different districts of Istanbul have settled in place of the Roma, not the local inhabitants of the area.

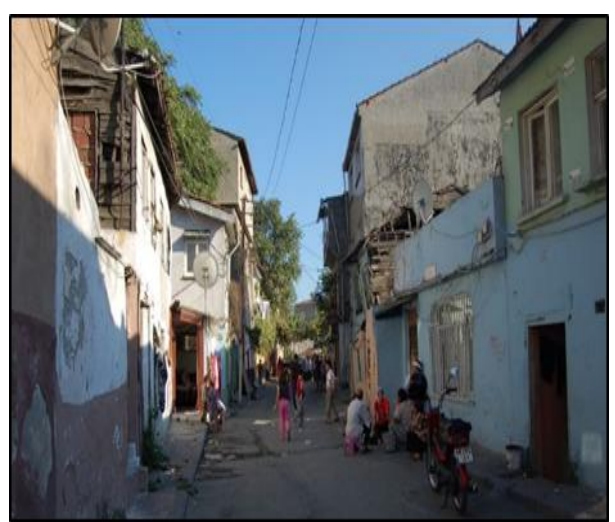

Figure 5. Sulukule - before (URL 8, 2018)

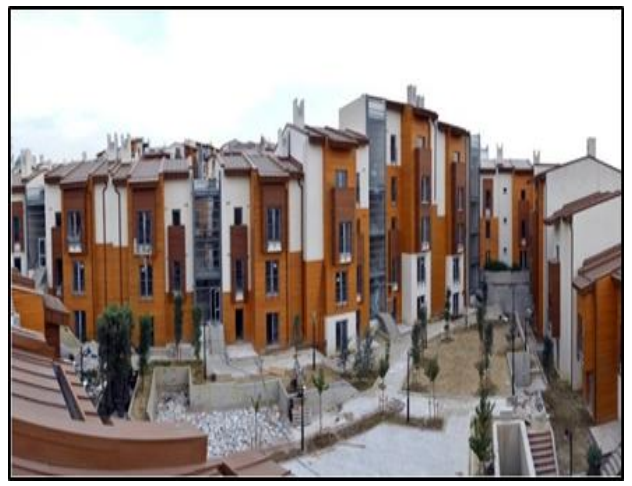

Figure 6. Sulukule - after (URL 8, 2018) 
Zeytinburnu province where the first illegal construction is seen is the first urban regeneration area in Istanbul (Kahraman, 2006). Zeytinburnu was the first industrial region of Istanbul. Due to industrial reasons in the region, the shanty process has increased. Then, in the district, the shanty houses were destroyed and instead tall apartment buildings were constructed. These developments challenged the urban way of life, including safety, health, and security (Nerse, 2013). After the 1999 Marmara earthquake, Istanbul Earthquake Master Plan was prepared and Zeytinburnu was selected as a pilot region (URL 9, 2018). At the end of the work, the necessity of reconstruction rather than strengthening buildings in Zeytinburnu has come to the forefront. It was determined that 2 thousand 295 out of 17 thousand were risky, and it was applied for 809 buildings and a demolition license was given to 390 . Up to now, 325 buildings have been demolished and reconstructed (URL 3 . 2018), (Figure 7, Figure 8).

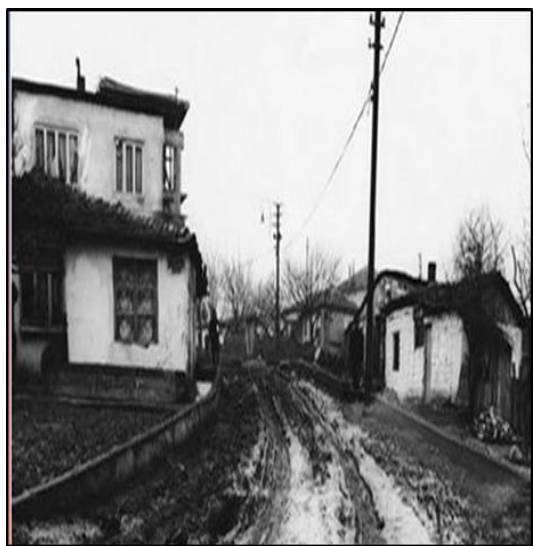

Figure 7. Zeytinburnu - before (URL 10, 2018)

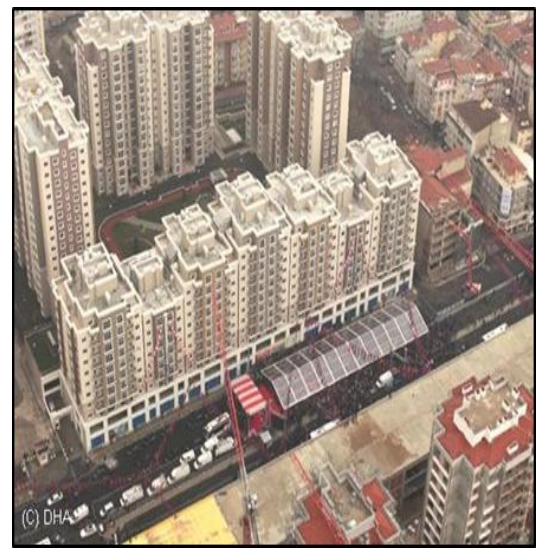

Figure 8. Zeytinburnu - after (URL 11, 2018)

Kağıthane, one of the villagers established in the immediate vicinity of the city walls of Istanbul, first came to the stage of history in 626. Kağıthane's history is as old as the history of Istanbul. Kuban depicts the historical structure of Istanbul, especially the development of the city with general lines, while Kagithane is also in this historical development (URL 12, 2018). 70,000 independent sections have been renewed in the district with 180,000 total independent sections. This shows that 36 percent of the population is transformed (URL 3, 2018). Kağıthane is the district where the most transformation takes place.

\section{Materials and Method}

Kağıthane District, one of the districts where migration is the most, was chosen as the study area of Nurtepe Street (Figure 9). 


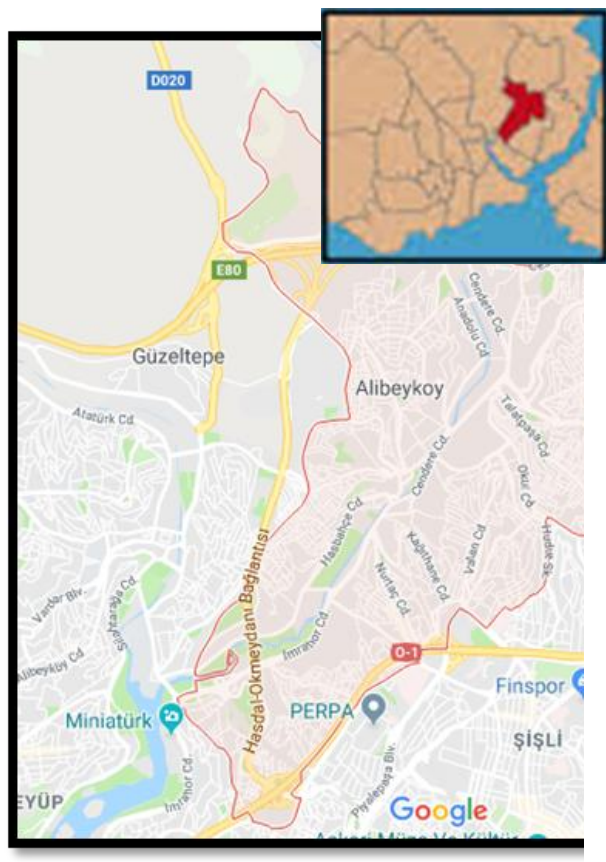

Figure 9. Kağıthane location map (URL 13, 2018)

Nurtepe developed as a residential area due to the topography of the region. Nurtepe Street is one of the shanty areas, which was established in the late 1960s. With the construction of Fatih Sultan Mehmet Bridge in the 1980s, the Kağıthane population is at the top of the increasing number of districts. The fact that urban regeneration studies have not progressed in line with their aims, that they cannot meet expectations, and that urban tissue and culture have begun to change have created the starting point of the study. Within the scope of the study, a survey was conducted in Nurtepe Street. The size of the sample was taken as 100 in the questionnaire study conducted by the respondents randomly and using the face-to-face interview technique.

\section{Results}

A survey was conducted to determine the change in the scope of the urban regeneration projects of Nurtepe, where the first structure started as a shanty settlement, and the impact of this change.
- $52.5 \%$ of the participants live in Nurtepe District, $2.5 \%$ live in Kağıthane Central District while the remaining $45 \%$ live in other districts of Istanbul except for Kağıthane and Eyüp.

- $37.5 \%$ are private-sector employees, $12.5 \%$ are students, $12.5 \%$ are retired, $12.5 \%$ are unemployed, $10 \%$ are workers, $7.5 \%$ of them are self-employed, $5 \%$ are housewives, $2.5 \%$ are artisans and so on.

- When the education status of the surveyed subjects was examined, $3 \%$ of the subjects were illiterate, $25 \%$ have primary school level, $42 \%$ have high school level, $22 \%$ are university graduates and $8 \%$ were graduate students.

- When asked if they think that urban regeneration has improved the environment, $60 \%$ answered "no" and 40\% answered, "yes" (Figure 10).

- When asked whether the urban regeneration meets the expectations, they answered that $60 \%$ were "no", 15\% were "partially yes", 2.5\% were "yes" and $22.5 \%$ were "other" (Figure 11).

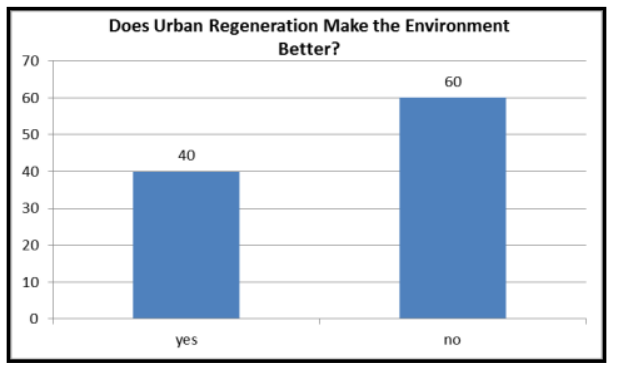

Figure 10. Thoughts of subjects about urban regeneration

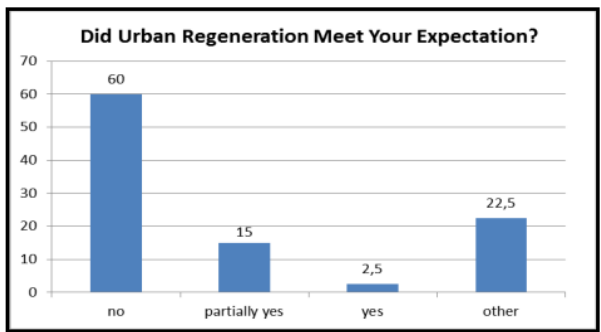

Figure 11. The expectations of subjects on urban regeneration 
- When asked whether their social relations with the new area where they live in continue after the urban regeneration, $56 \%$ of the respondents stated that they had a disconnection in social relations, $39 \%$ of the respondents said that their relatives had continued and $5 \%$ had no idea.

- In response to the question of how urban regeneration has changed economically (from house prices, rent, dues, etc.), respondents answered with $64 \%$ negative, $23 \%$ positive and $3 \%$ no opinion. As a result of the urban regeneration, respondents in the question of housing standards (size of the house and/or workplace, sunlight, humidity, etc.) answered with $48 \%$ positive, $50 \%$ negative and $2 \%$ no idea. When asked about the effects of urban regeneration on their houses, $80 \%$ of the respondents said that they were not affected and $20 \%$ said that their houses were renewed by urban regeneration. $62.5 \%$ of those who were directly affected by urban regeneration said "there was a decrease in the case of green area" and $37.5 \%$ of them said that "there is no change in the case of green area".

- When asked about the purpose of the urban regeneration projects, $62.5 \%$ of the survey respondents were asked to "provide rent", $20 \%$ to "build stable buildings", $7.5 \%$ to "create a more livable environment" $7.5 \%$ to "raise the living standards of the people living in the urban regeneration zone" and $2.5 \%$ as "other".

- $64.3 \%$ of the income group between $0-1800 \mathrm{TL}$ and $65 \%$ of the income group of 1800-3000 TL said that the purpose of urban regeneration is to provide rent.

- After urban regeneration, $79.2 \%$ of the residents who say that the green areas around the building are decreasing determine that the purpose of urban regeneration is to provide rent.

- $\quad 83.3 \%$ of respondents, who think that urban regeneration does not make the environment better, said that the purpose of urban regeneration is to provide rent.

- As a result of examining the satisfaction level of the income group and the urban regeneration, it is seen that the purpose of urban regeneration is to provide rent as the foreground.

\section{Discussion}

One of the most important tools for the solution of housing problems for different purposes is urban regeneration projects. Thus, these projects are the preferred policy in Turkey for sanitization and regeneration of shanties. Throughout history, in the formation of urban space in our country, there have been long-lived practices that integrate social life, have rational and creative solutions to the limited possibilities of society, but have seen heavy turnover over time in terms of lifestyle and utilization of technology. It is questionable to apply the same solutions to different problems of the cities. For example, the destruction of historical buildings and the creation of modern and safe living spaces will bring the question 'To whom and what for regeneration'?

While urban regeneration is being done, it is necessary to work towards the needs of the users.

The following preconditions are suggested while urban regeneration projects are being prepared;

- $\quad$ Firstly getting together with the users and making public meetings in the neighborhood,

- The preferences, needs, and expectations of local people are accepted as one of the most important priorities at these meetings, 
- The contribution of green spaces to strengthening social relations is not ignored and the areas to address for all age groups are absolutely separated,

- The construction of the buildings taking into account the history and architecture of the city should not be ignored.

According to all these results, it is seen that when the urban transformation projects are being carried out - as it is the case in many European cities that have reached success urban and regeneration projects should address the needs of the users. Then, they should be arranged and planned as comprehensive projects to protect the cultural characteristics, architecture and historical character of the city.

\section{Conclusion}

In Turkey, in the last fifty years, urbanization has been conditioned by the market, which resulted in unplanned housing construction. Thus, urbanization and construction could allegorically fit into the following open-ended statement "richer will be richer, poorer will be poorer" (Koçak and Tolanlar, 2008).

While the problems that cause the urban regeneration studies are reduced to the regeneration of the physical space, the economic, social and cultural dimensions of the settlement are generally not taken into consideration. The aesthetics and diversity of constructions are important in terms of identity development. The good quality of the building will also help to improve identity by a positive impact on the city's appearance. Local governments should develop local programs that take into account the specific needs of sub-groups within the local population. Local governments should adopt common goals to improve socio-economic conditions while identifying the means to meet the needs of the population.
The influence of the citizens could directly affect urban transformation. The constant construction processes in the city often result in pollution of the environment, the gradual disappearance of empty spaces, crowded areas, the gradual disappearance of neighborhood cultures, and the formation of closed societies. In this regard, the citizens together with policy-makers and architects should take an active role in urban planning and regeneration. In this regard, human and environment-oriented projects shall increase the quality of life in the city. This requires a holistic approach to urban planning and regeneration. 


\section{References}

Altınöz, İ. (2007). Gypsies in the Ottoman State Administration in the Century of XVI., Foreigners of the Earth, Gypsies, Simurg Publication, Istanbul.

Ataöv, A. and Osmay, S. (2007). Methodological Approach to Urban regeneration in Turkey. METU JFA 24 (2):57-82.

Belge, R. and Çeker, A. (2015). A Case of Urban Regeneration in Istanbul: Gentrification. Turkey Geographical Journal 65: 77-86.

Cohen B. (2006). Urbanization in developing countries: Current trends, future projections, and key challenges for sustainability. Technology in Society 28; 63-80.

Çağlayan, S. (2013). Urban Sociology. Anadolu University Publication No: 2978, Open Education Faculty Publication No: 1932.

Dündar, D. (2001). Models of Urban Transformation: Informal Housing in Ankara. Cities, 18 (6); 391401.

Es, M. (2012). Urban Regeneration. Magnet Magazine, Yalova University iiBF Ankara Chamber of Industry Publication Organization | July /August.

Kahraman T. (2006). Urban Regeneration Projects and Planning Processes in Istanbul. Planning Magazine, 2; 93-103, Chamber of Urban Planners Publication.

Kıyak Ingin, A. and Islam, T. (2011). The Reordering of a Romany Neighbourhood. Interface Planning Theory and Practice. 12(1): 115-153, Routledge Taylor\&Francis Group.

Koçak, H. and Tolanlar, M. (2008). Urban Regeneration Practices: Aydın and Afyonkarahisar Examples. Afyon Kocatepe University, i.i.B.F. Magazine 10 (2): 397-415.

Mbanaso M. U. and Ozden, K., 2017. Urbanization, Migration and Sustainable Development: A case Analysis of Nigeria. Nigerian Studies Review, 2; 23-46.

Nerse, S. (2013). Zeytinburnu Textile Workers' Future on the Urban Regeneration Project, VII. National Society of Sociology New Social Structures: Transitions, Intersections, Deviations, 3: 591-601, 2-5 October, Muğla.

Özkan, M. (2011). Urban Politics with Culture and Art in Istanbul. Skop Magazine; 1.

Roberts, P. (2000). The Evolution, Definition and Purpose of Urban Regeneration. Urban Regeneration a Handbook, p. 14.

Ulu, A. and Karakoç, í. (2004). The Impact of Urban Change on Urban Identity. Planning Magazine, 29: 59-66, Chamber of Urban Planners Publication of TMMOB.

Uysal, U. E. (2006). Applicability of Gentrification Theories in Istanbul: An Example of Cihangir. Planning (2), 77-92.

URL 1. (2018). https://tr.sputniknews.com/turkiye/201802011032060038-tuik-turkiye-nufus/. Retrieved: 12.02.2018.

URL 2. (2018). http://www.canlimobesekameraizle.com/istanbul-uydu-goruntusu-haritasi/. Retrieved: 10.02.2018.

URL 3. (2018). https://www.gninsaat.com.tr/istanbulda-kentsel-donusumun-son-durumu. Retrieved: 16.01.2018.

URL 4. (2018). https://yandex.com.tr/gorsel/search?text=cihangir\%20beyoğlu\%20eski\%20fotoğraflar\&img_url=h ttps\%3A\%2F\%2Fi.pinimg.com\%2F736x\%2Fbe\%2Fee\%2Fce\%2Fbeeece3c0e720b74c5749d3f29099 32e--bir-zamanlar-istanbul.jpg\&pos=29\&rpt=simage. Retrieved: 02.02.2018.

URL 5. (2018). http://www.spo.org.tr/resimler/ekler/705e1164a8394aa_ek.pdf. Retrieved: 10.02.2018.

URL 6. (2018). http://www.veziroglugayrimenkul.com/tarlabasi-360-projesi/. Retrieved: 20.04.2018.

URL 7. (2018). http://www.mimdap.org/?p=30774. Retrieved: 10.02.2018.

URL 8. (2018). http://www.siddethikayeleri.com/portfolio/sulukule-sen-sakrak-muzikli-yasamdolu/\#.Wsu5edRua1s. Retrieved: 10.03.2018.

URL 9. (2018). http://eski.zeytinburnu.istanbul/Document/FileManager/tk4_kentsel.pdf. Retrieved: 20.01.2018.

URL 10. (2018).

https://yandex.com.tr/gorsel/search?p=5\&text=Zeytinburnu\%20Gecekonduları\%201960\&img_url =http\%3A\%2F\%2Fslideplayer.biz.tr\%2Fslide\%2F2746941\%2F10\%2Fimages\%2F13\%2Fhttp\%3A\%2F www.zeytinburnu-

bld.gov.tr\%2Fbel_zeytinburnu\%2F\%2Bzeytinburnu\%2Fgecekondulasma_sureci.cfm.jpg\&pos=153 \&rpt=simage. Retrieved: 15.04 .2018$.

URL 11. (2018).

https://yandex.com.tr/gorsel/search?text=Zeytinburnu\%20Kentsel\%20Dönüşüm\&img_url=https\% 
3A\%2F\%2Fimg.sondakika.com\%2Fhaber\%2F353\%2Fzeytinburnu-nda-kentsel-donusumyikimlarinin-4361353_o.jpg\&pos=0\&rpt=simage. Retrieved: 15.04.2018.

URL 12. (2018). http://www.kagithane.gov.tr/ilcemizin-tarihcesi. Retrieved: 10.04.2018.

URL 13. (2018).

https://www.google.com.tr/maps/place/Ka\%C4\%9F\%C4\%B1thane\%2F\%C4\%B0stanbul/@41.0898 147,28.9775819,13z/data=!4m5!3m4!1s0x14cab6ea321836e1:0xbf71bapıştıralım4bd7c23d138!8 m2!3d41.0814028!4d28.9819731. Retrieved: 15.04.2018. 
